\title{
Evaluating Lung Cancer with Tumor Markers: CEA, CA 19-9 and CA 125
}

\section{Akciğer Kanserinin Tümör Belirteçleri ile Değerlendirilmesi: CEA, CA 19-9 ve CA 125}

\author{
Suphi Aydın', @Aydın Balcı2', Muhammet Emin Düz ${ }^{3}$ \\ 'Afyonkarahisar Health Sciences Universty, Departmen of thoracic Surgery, Afyonkarahisar, TURKEY \\ ${ }^{2}$ Afyonkarahisar Health Sciences Universty, Departmen of pulmonology, Afyonkarahisar, TURKEY \\ ${ }^{3}$ Dr.Amasya Sabuncuoğlu Training and Research Hospital, Departmen of Clinical Biochemistry, Amasya, Turkey
}

\begin{abstract}
Aim: Lung cancer (LC) is a common and mortal malignancy. Tumor biomarkers are measurable biochemicals associated with cancer cells. Tumor markers cannot diagnose cancer; instead, they can be used as laboratory tests to support the diagnosis. In this study, we aimed to investigate the place of tumor markers in lung cancer histological types.
\end{abstract}

Material and Method: The study included 121 stage IV lung cancer patients, 79\% of whom were male, aged between 33-84 years, who were admitted to the pulmonology and thoracic surgery departments of the hospital. CEA, CA 19-9, CA 125 were studied to compare survival with the immunoassay technique and LDH was analyzed for tumor burden and turn-over determination by enzymatic method. Patients were divided into groups of metastasis numbers and the life span after diagnosis to evaluate the clinical parameters in detail.

Result: CEA in the adenocarcinoma type, CA 19-9 in the small cell subtype, CA 125 in the squamous type were significantly higher than the other histological subtypes $(p=0.037, p=0.031, p=0.021)$. CEA, CA 19-9, CA 125 values were significantly increased in patients with more than two metastases $(p=0.047, p=0.039, p=0.028)$. When the tumor was divided into three groups as $<3 \mathrm{~cm}, 3-5 \mathrm{~cm},>5 \mathrm{~cm}$, CA 19-9 and CEA levels increased in proportion to tumor diameter, while CA 12-5 levels did not show a statistical relationship.

Conclusion: CEA and CA 19-9 for adenocarcinoma type, CA 19-9 for small cell lung cancer and CA 125 for squamous cell type can help predict patients' prognosis.

Keywords: Cancer, biomarker, tumor, metastasis

\section{Öz}

Amaç: Akciğer kanseri (LC) yaygın ve ölümcül bir malignitedir. Tümör biyobelirteçleri, kanser hücreleriyle ilişkili ölçülebilir biyokimyasallardır. Tümör belirteçleri kanseri teşhis edemez; bunun yerine tanıy desteklemek için laboratuar testleri olarak kullanılabilirler. Bu çalışmada tümör belirteçlerinin akciğer kanseri histolojik tiplerindeki yerini araştırmayı amaçladık.

Gereç ve Yöntem: Çalışmaya hastanemiz göğüs hastalıkları ve göğüs cerrahisi bölümlerine başvuran\% 79'u erkek 33-84 yaş aralığında 121 evreIVakciğer kanseri hastasıalındı.CEA,CA 19-9,CA 125, immünoassay tekniği ile çalışılı. Sağkalımı predikte edebilme değerleri araştırıldı. LDH, enzimatik yöntemle tümör yükü ve dönüşüm tespiti için analiz edildi. Hastalar, klinik parametreleri ayrıntılı olarak değerlendirmek için metastaz sayıları ve tanı sonrası yaşam süresine göre gruplara ayrıldı.

Bulgelar: Adenokarsinom tipinde CEA, küçük hücre alt tipinde CA 19-9, skuamöz tipte CA 125 diğer histolojik alt tiplere göre anlaml derecede yüksekti $(p=0,037, p=0,031, p=0,021)$. Ikiden fazla metastaz। olan hastalarda CEA, CA 19-9, CA 125 değerleri anlamlı olarak arttı $(p=0,047, p=0,039, p=0,028)$. Tümör $<3 \mathrm{~cm}, 3-5 \mathrm{~cm},>5 \mathrm{~cm}$ olarak üç gruba ayrıldığında, CA 19-9 ve CEA düzeyleri tümör çapı ile orantılı olarak artarken, CA 12-5 düzeyleri istatistiksel bir ilişki göstermedi.

Sonuç: Adenokarsinom tipi için CEA ve CA 19-9, küçük hücreli akciğer kanseri için CA 19-9 ve skuamöz hücre tipi için CA 125, hastaların prognozunu tahmin etmeye yardımcı olabilir.

Anahtar Kelimeler: Kanser, biyobelirteç, tümör, metastaz 


\section{INTRODUCTION}

Lung cancer (LC) is a commonplace and mortal malignancy beyond humans. LC has a $12.3 \%$ prevalence and 1.2 million incidences. LC causes 1.1 million deaths globally and is responsible for $17.8 \%$ of the total number of cancer deaths per year. ${ }^{[1]}$ There are new technologies for early detection of lung cancer, but we need minimal invasive and cheap methods. ${ }^{[2]}$

Tumor markers are biochemical indicators of a tumor. In clinical practice, it is a molecule in circulation within plasma and body fluids. Tumor biomarkers are measurable biochemicals associated with cancer cells. Tumor markers cannot diagnose cancer; instead, they can be used as laboratory tests to support the diagnosis. ${ }^{[3]}$ Tumor markers are useful for screening a high-risk population for cancer, making a diagnosis and prognosis in specific cancer types and monitoring the course in a patient in remission or while receiving surgery, radiation, or chemotherapy. The ideal marker should be tissue-specific for different cancer types. A positive result should arise only in patients with malignancy, one that would correlate with stage and response to treatment and that could be easily and reproducibly measured. ${ }^{[4]}$

Carcinoembryonic antigen (CEA) describes a set of positively related glycoproteins involved in cell adhesion. Gastrointestinal tissue usually produces CEA during fetal development, but the production stops before birth. Consequently, CEA is typically present at deficient levels in healthy adults (about $2-4 \mathrm{ng} / \mathrm{mL}$ ). However, the serum levels are higher in some types of cancer, which means scientists can consider it a tumor marker in clinical tests. Serum levels can also elevate in heavy smokers. [4] Quantifying CEA in the blood help evaluate individuals diagnosed with cancer. CEA frequently associates commonly with colorectal cancer; it also elevates in other malignancies such as breast, liver, stomach and pancreas. Benign diseases can boost CEA levels too, so it is hard to use it for cancer screening. ${ }^{[5]}$

CA-125, also known as MUC16 (mucin 16), is the MUC16 geneencoded protein of humans. MUC16 takes place within mucin family glycoproteins. Scientists use CA-125 as a tumor marker or biomarker that may elevate in blood with specific types of cancers or other benign conditions. MUC16 (CA-125) plays a role in advancing tumorigenesis and tumor proliferation by various mechanisms. Testing of CA-125 blood levels is useful in treating ovarian cancer. While the test gives helpful information for women already have ovarian cancer, CA-125 testing is not yet practical as a screening method because of the uncertain correlation between CA-125 levels and cancer. ${ }^{[6-8]}$

CA 15-3, for Carcinoma Antigen 15-3, is a tumor marker for many cancer types, most particularly breast cancer. CA 15-3 and associated CA 27-29 are different epitopes on the same protein antigen product of the breast cancer-associated MUC1 gene. Elevated CA15-3, combined with alkaline phosphatase (ALP), is associated with an increased risk of early breast cancer recurrence. Both CA 15-3 and CA 27-29 could elevate in patients with benign ovarian cysts, mild breast disease and benign liver disease. CA 15-3 also promotes in cirrhosis, sarcoidosis and lupus. ${ }^{[9,10]}$ CA 15-3 assay values do not elevate in most normal individuals and frequently advance in breast cancer patients serums. Elevated CA 15-3 levels of other tumors are lung, colon, pancreas, primary liver, ovary, cervix and endometrium. ${ }^{[11]}$

Carbohydrate antigen 19-9 (CA19-9) is usually attache to cells via O-glycans. It has a crucial role in cell-to-cell recognition processes. It is also a tumor marker used primarily in the management of pancreatic cancer. ${ }^{[1]}$ There are below 1,000 $\mathrm{U} / \mathrm{mL}$ CA 19-9 levels with benign conditions such as cirrhosis, cholestasis and pancreatitis. Lewis negative people (5\%-7\% of the population) do not express CA 19-9 due to the lack of the enzyme fucosyltransferase needed for CA 19-9 production. A low or undetectable serum CA 19-9 concentration is not informative regarding cancer recurrence. ${ }^{[12]}$ This study aims to utilize routine tumor markers to evaluate LC prognosis in order to stage, grade, number of metastases and tumor mass.

\section{MATERIAL AND METHOD}

This retrospective case-control study was managed at Afyonkarahisar Health Sciences University Faculty of Medicine in Afyonkarahisar, Turkey, between January 2010 to January 2020. The institutional ethical committee of university approved the study and consent was taken from each patient. The study included 121 metastatic stage IV lung cancer patients, 79\% of whom were male, aged between 33-84 years, who were admitted to the pulmonology and thoracic surgery departments of the hospital. Stage and histological classification were determined according to the World Health Organization (WHO) lung cancer classification. Patients with a history of carcinoma, other infection, auto-immune disease, organ failure and pregnancy were excluded from the study. CEA, CA 19-9 and CA 125 were studied to compare survival with the immunoassay technique and LDH was analyzed for tumor burden and turn-over determination by enzymatic method. The CEA test's reference range in the healthy population was determined as $0-2.5 \mathrm{ng} / \mathrm{mL}$ and $0-5.0 \mathrm{ng} / \mathrm{mL}$ in smokers. The reference range for CA 125 is $<35 \mathrm{kU} / \mathrm{L}$ and for CA $19-9<37 \mathrm{U} /$ $\mathrm{mL}$. Patients were divided into groups of metastasis numbers and the life span after diagnosis to evaluate the clinical parameters in detail. Jasp 0.14.0.0 statistical program was used in the analysis of the data obtained. Results are demonstrated as mean \pm standard deviation. Mean differences in tumor markers were assessed by the "paired t-test" The correlation of parameters with clinical situations was analyzed with "Pearson's" bivariate correlation analysis. A p-value of $<0.05$ was considered significant, with a $95 \%$ confidence interval. The relationship between tobacco use and tumor markers was compared with the "Mann-Whitney test".

\section{Ethic approval}

The study was conducted in accordance with good clinical practice and the Declaration of Helsinki. The study was approved by the ethics committee of Afyonkarahisar Health Sciences University Medical Faculty Hospital (No: 2011- KAEK-2 2020/13). 


\section{RESULTS}

We had 121 stage IV lung cancer with a mean age of 64 and a $\% 79$ male ratio. The histological type in most of the patients was adenocarcinoma, with a rate of $47 \%$. There was no difference in histological and clinical classes in terms of age and gender. CEA in the adenocarcinoma subtype, CA 19-9 in the small cell subtype and CA 125 in the squamous type were significantly higher than the other histological subtypes $(p=0.037, p=0.031, p=0.021)$ (Figure 1A, 1B, 1C).

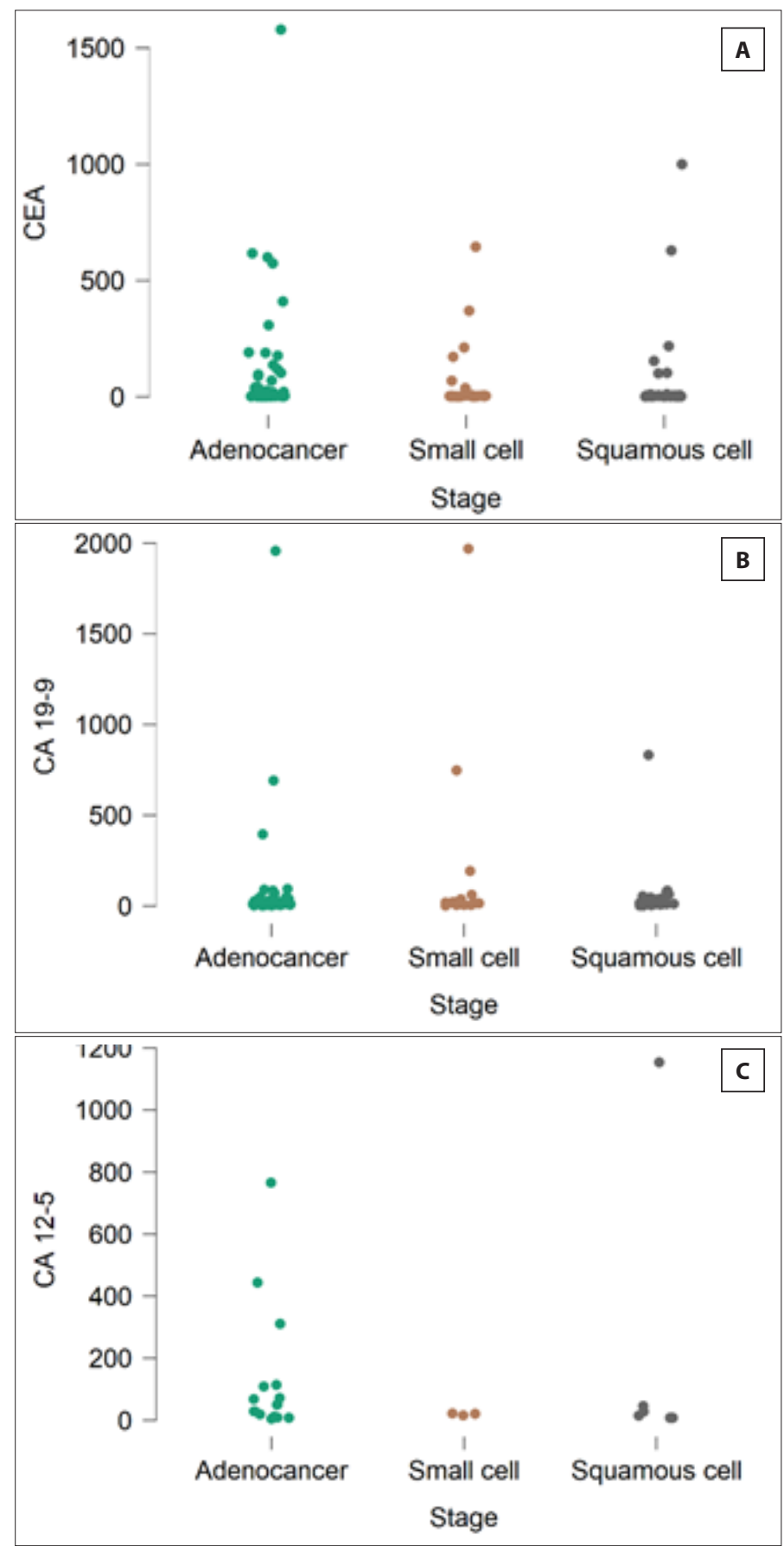

Figure 1. A) CEA levels for all stage, B) CA 19-9 levels for all stage, C) CA 125 levels for all stage
Smoking was more elevated in the small cell and squamous subtypes than adenocarcinoma subtypes, but no statistically significant difference was found ( $p=0.806$ ). CEA, CA 19-9 and CA 125 values were significantly increased in patients with more than two metastases $(p=0.047, p=0.039, p=0.028)$. CEA values were within the reference range at $87 \%$ in patients with two or fewer metastases, while CA 19-9 values were within the reference range at $83 \%$ (Figure $\mathbf{2 A}, \mathbf{2 B}, \mathbf{2 C}$ ).
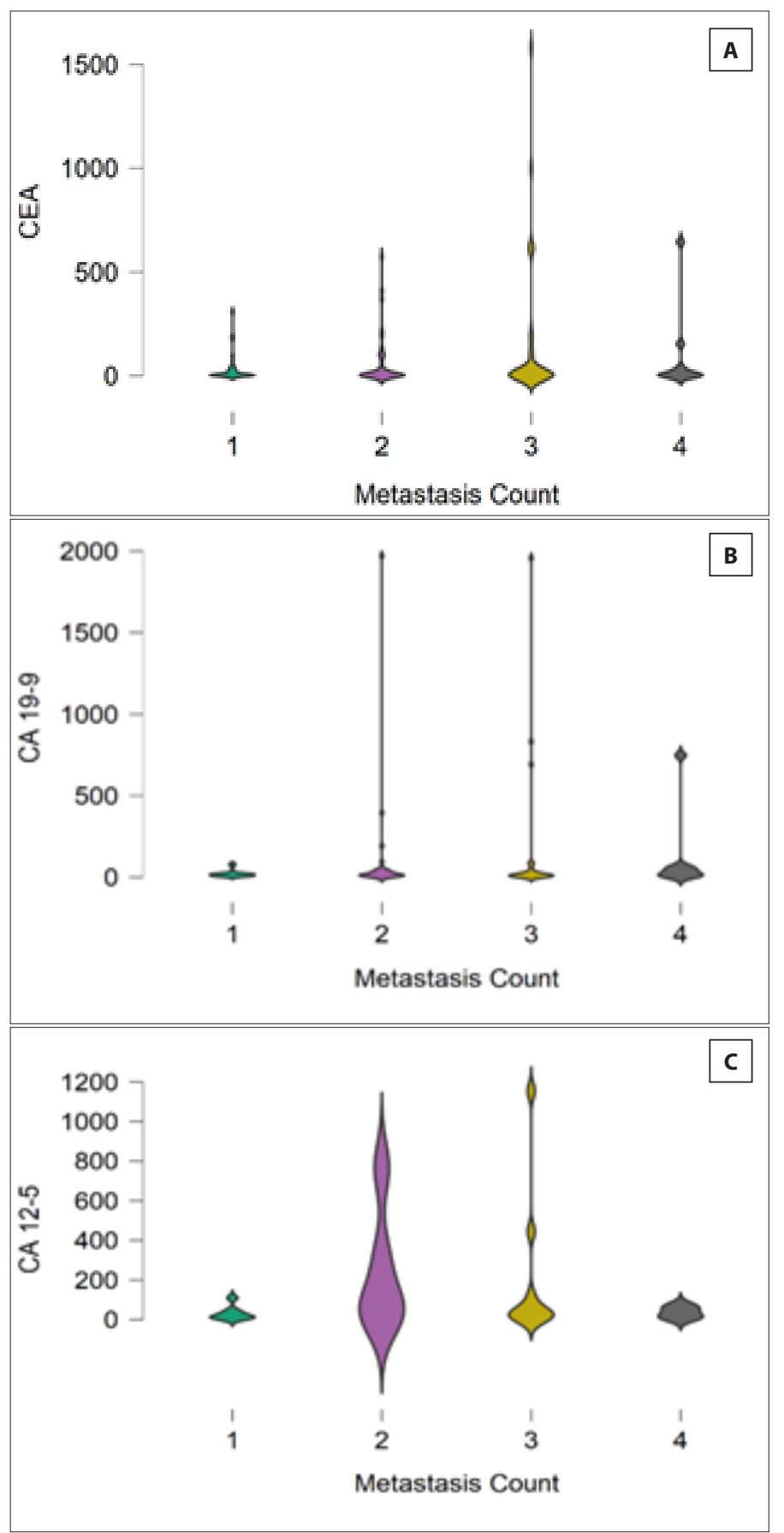

Figure 2. A) CEA levels for the number of metastases, B) CA 19-9 levels for the number of metastases, C) CA 125 levels for the number of metastases 
No difference was found between the number of metastases and $L D H$ levels. When the tumor was divided into three groups as $<3 \mathrm{~cm}, 3-5 \mathrm{~cm}$ and $>5 \mathrm{~cm}$, CA $19-9$ and CEA levels increased in proportion to tumor diameter, while CA 125 levels did not show a statistical relationship. CEA and CA 19-9 values were found to be significantly lower in the surviving patients compared to the patients who died, whereas CA 125 values were found to be considerably higher (Figure 3A, 3B, 3C).

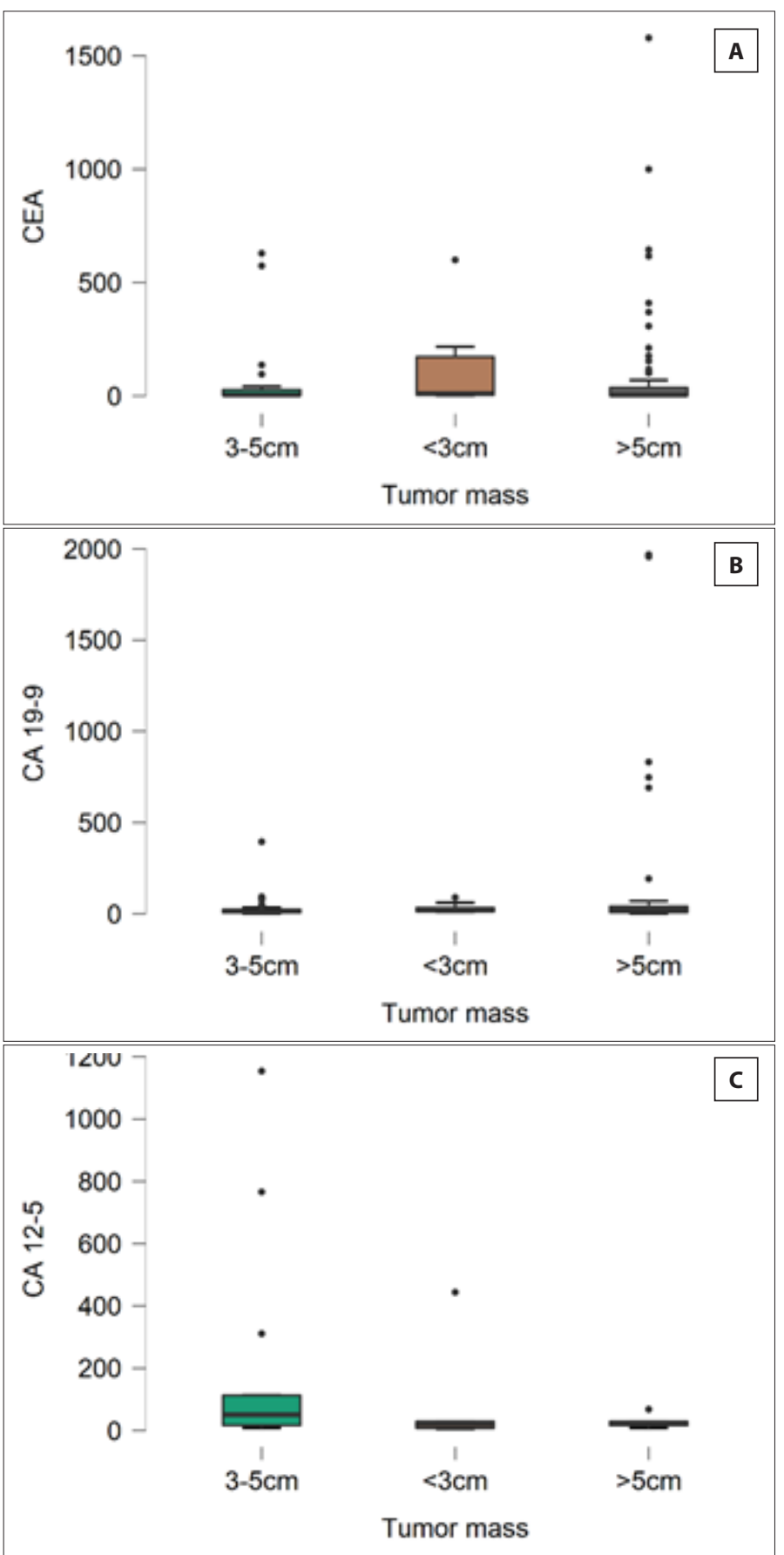

Figure 3. A) CEA levels for tumor mass, B) CA 19-9 levels for tumor mass, C) CA 125 levels for tumor mass
When the adjustment was made according to the number of metastases, CEA, CA 19-9 and CA 125 values were statistically significantly higher in the adenocarcinoma subtype. Histological comparison of biocemical parameters is given in Table 1.

Table 1. Comparison of CEA, CA 19-9, CA 125, LDH and Survival mean levels and $p$ values according to lung cancer subtypes.

\begin{tabular}{lcccc} 
& $\begin{array}{c}\text { Adenocarcinoma } \\
(\mathbf{N}=\mathbf{5 7})\end{array}$ & $\begin{array}{c}\text { Squamous cell } \\
\text { carcinoma } \\
\mathbf{( N = 3 6 )}\end{array}$ & $\begin{array}{c}\text { Small cell } \\
\text { carsinoma } \\
(\mathbf{N}=\mathbf{2 8})\end{array}$ & $\mathbf{p}$ \\
\hline $\begin{array}{l}\mathrm{CEA} \\
(\mathrm{ng} / \mathrm{mL})\end{array}$ & $185.3 \pm 72.8$ & $42.5 \pm 23.7$ & $54.1 \pm 36.1$ & 0.037 \\
$\begin{array}{l}\mathrm{CA} 19-9 \\
(\mathrm{U} / \mathrm{mL})\end{array}$ & $272.2 \pm 204.2$ & $176.1 \pm 113.2$ & $50.7 \pm 29.1$ & 0.031 \\
$\begin{array}{l}\mathrm{CA} 125 \\
(\mathrm{kU} / \mathrm{L})\end{array}$ & $137.8 \pm 55$ & $209.8 \pm 88.9$ & $19.6 \pm 1.8$ & 0.021 \\
$\begin{array}{l}\mathrm{LDH} \\
(\mathrm{U} / \mathrm{L})\end{array}$ & $676.5 \pm 134$ & $371.3 \pm 50$ & $854.2 \pm 170$ & 0.11 \\
$\begin{array}{l}\text { Survival } \\
(\text { Months })\end{array}$ & $11.4 \pm 1.6$ & $11.3 \pm 1.7$ & $12.7 \pm 1.8$ & 0.853 \\
\hline
\end{tabular}

\section{DISCUSSION}

Studies have shown a significant correlation between CEA levels and nodal involvement and survival of the adenocarcinoma subtype. ${ }^{[13]}$ Poor prognosis is often seen with increasing CEA levels. Preoperative CEA measurement in earlystage non-small cell LC patients may help identify patients with advanced stages that could not be identified on CT scans. ${ }^{[14]}$ It has been stated in different studies that CA 19-9 levels are increased in small cell lung cancer, but it is not handy for clinical use. On the contrary, it has been reported that CA 19-9 levels are significantly increased in adenocarcinoma patients because it is secreted from the bronchial epithelium and it is beneficial in prognosis. ${ }^{[15]}$ Other studies have been shown that CA 125 levels increase in the squamous subtype and even its use in combination with other tumor markers will increase the sensitivity of the test in terms of diagnosis and prognosis. ${ }^{[16]}$ Our study results were compatible with the literature in terms of CEA and CA 125. Although we achieved promising results in terms of CA 19-9, literature data indicated that this marker increased in adenocarcinoma subtype rather than small cell lung cancer. ${ }^{[17]}$

A statistically significant relationship was found in a study between CEA, CA 19-9 and CA 125 parameters with lymph node involvement, tissue and organ metastases. ${ }^{[18]}$ Studies have also stated that CEA values correlate with adenocarcinoma subtype and CA 125 values with squamous subtype metastasis, prognosis and estimated survival time. ${ }^{[19]}$ As a result of our study, we determined that tumor markers were associated with the number of metastases and prognosis in LC cases of different histological subtypes, following the literature. While detailed information on lung cancer tumor burden is limited in studies, neuron-specific enolase can be considered a reliable marker of tumor burden in lung cancer patients receiving chemotherapy. Simultaneously, CYFRA 21.1 expression appears to be less associated with changing and 
predicting tumor mass in squamous cell lung cancer. It has been reported that these two markers can be used together. [20] Although we found a significant relationship between tumor markers we evaluated in our study and tumor burden, we could not find literature data to support our results.

The researchers stated that the parameters of CEA, CYFRA21-1 and CA-125, with CA 125 being more valuable, were significantly associated with the survival of the patients (21). A study involving 105 patients with all-stage non-small cell lung cancer reported that CEA is a significant negative prognostic factor. ${ }^{[21]}$ The role of CA-125 in lung cancer is not clearly known. Some studies have found prognostic predisposition in operated non-small cell LC patients, but there is not much data on the advanced disease. ${ }^{[22]}$ The search for early-stage tumor markers has been included in our study of glycoproteins CA 19-9 and CA 125 which are recognized by monoclonal antibodies. These markers are practically valuable for malignancies in the digestive system and it is thought to be useful to investigate their value in the diagnosis of lung cancer. The usefulness of these parameters in evaluating lung cancer appears to be small because, although they are specific, they are insensitive in the advanced stages of the disease. However, its increasing levels may be valuable in giving pre- and postoperative advice. ${ }^{[23,24]}$ In our study, although CEA and CA 19-9 were found to be increased in patients with poor clinical status following the literature, we found that CA 125 levels were decreased. We could not comply with the literature in terms of CA 125 because we included patients of all histological types in our study. When all histological types are evaluated, the proportionally small percentage of the squamous type associated with CA 125 may explain our results.

Our study found that CEA and CA 19-9 parameters increased in patients with metastases in at least two regions, regardless of histological structure. These tumor markers, which are found in small amounts in healthy individuals' blood serum, are expressed from normally functioning tissues. Until metastasis develops in more than two regions, cancer cells may have provided sufficient vascular invasion and exit to the circulation. However, they may not be able to proliferate to increase these parameters massively. This may be why the tumor could not reach the abnormal level of synthesis of these glycoproteins. This hypothesis can explain our results. The tumor markers we studied in LC, whose histological structure is adenocarcinoma, increased at a lower level than other subtypes. This may be because adenocarcinoma tissue proliferates more slowly than other tumor types and expresses surface glycoprotein later. Alternatively, the patient group we selected may not be suitable for this comparison.

\section{CONCLUSION}

As an inexpensive, practical, patient-effortless method, tumor markers can be used to determine the severity of lung cancer and predict survival. The critical point here is which marker to choose to monitor which histological background.
CEA and CA 19-9 for adenocarcinoma, CA 19-9 for small cell lung cancer and CA 125 for squamous cell histologic type can help predict patients' prognosis. These three markers are widespread, inexpensive, easily accessible and clinically informative worldwide and seem useful in evaluating lung cancer patients.

\section{ETHICAL DECLARATIONS}

Ethics Committee Approval: The study was approved by the ethics committee of Afyonkarahisar Health Sciences University Medical Faculty Hospital (No: 2011- KAEK-2 2020/13)..

Informed Consent: Because the study was designed retrospectively, no written informed consent form was obtained from patients.

Referee Evaluation Process: Externally peer-reviewed. Conflict of Interest Statement: The authors have no conflicts of interest to declare.

Financial Disclosure: The authors declared that this study has received no financial support.

Author Contributions: S.A. and A.B. conceived the presented idea. S.A, A.B and M.E.D. developed the theory and performed the computations. A.B and M.E.D. verified the analytical methods. S.A. supervised the findings of this work. All authors discussed the results and contributed to the final manuscript. All authors provided critical feedback and helped shape the research, analysis and manuscript.

\section{REFERENCES}

1. Smith RA, Cokkinides V, Eyre HJ. Cancer screening in the United States, 2007: a review of current guidelines, practices, and prospects. CA Cancer J Clin 2007;57:90-104.

2. MacMahon H, Engelmann R, Behlen FM, et al. Computer-aided diagnosis of pulmonary nodules: results of a large-scale observer test. Radiology. 1999;213:723-726.

3. Bhatt AN, Mathur R, Farooque A, Verma A, Dwarakanath BS. Cancer biomarkers - Current perspectives. Indian J Med Res. 2010;132:129-49.

4. Sung $\mathrm{HJ}$, Cho JY. Biomarkers for lung cancer diagnosis and their advances in proteomics. BMB Rep. 2008;41:615-625. DOI: 10.5483/ BMBRep.2008.41.9.615.

5. Gan N, Jia L, Zheng L. A sandwich electrochemical immunosensor using magnetic DNA nanoprobes for a carcinoembryonic antigen. Int J Mol Sci 12 (11): 7410-23.

6. Perkins GL, Slater ED, Sanders GK, Prichard JG. Serum tumor markers. http://www.aafp.org/afp/2003/0915/p1075.html. Am Fam Physician. 2003;15:1075-1082.

7. Yin BW, Lloyd KO. Molecular cloning of the CA125 ovarian cancer antigen: identification as a new mucin, MUC16. J Biol Chem 276 (29): 27371-5.

8. Yin BW, Dnistrian A, Lloyd KO. Ovarian cancer antigen CA125 is encoded by the MUC16 mucin gene. Int J Cancer 98 (5): 737-40.

9. Bast RC, Xu FJ, Yu YH, Barnhill S, Zhang Z, Mills GB. CA 125: the past and the future. Int J Biol Markers. 13 (4): 179-87.

10. Duffy MJ, Duggan C, Keane R, et al. High preoperative CA 15-3 concentrations predict adverse outcome in node-negative and nodepositive breast cancer: a study of 600 patients with histologically confirmed breast cancer. Clin. Chem. 50 (3): 559-63.

11. Keshaviah A, Dellapasqua S, Rotmensz N, et al. CA15-3 and alkaline phosphatase as predictors for breast cancer recurrence: a combined analysis of seven International Breast Cancer Study Group trials. Ann Oncol 2007;18(4):701-8. 
12. Perkins, G, Slater E, Sanders G, Prichard J. Serum tumor markers. Am Fam Physician. 2003;68(6):1075-82.

13. Tomita M, Ayabe T, Chosa E, Nakamura K. Correlation between Serum Carcinoembryonic Antigen Level and Histologic Subtype in Resected Lung Adenocarcinoma. Asian Pac J Cancer Prev. 2015;16(9):3857-60.

14. Nasralla A, Lee J, Dang J, Turner S. Elevated preoperative CEA is associated with subclinical nodal involvement and worse survival in stage I non-small-cell lung cancer: a systematic review and meta-analysis. J Cardiothorac Surg. 2020;15(1):318. doi:10.1186/s13019-020-01353-2

15. Prieto De Paula JM, Mayor Toranzo E, Gallardo Borge L, Franco Hidalgo S. Small-cell lung cancer and elevated CA 19.9 tumor marker levels. Arch Bronconeumol. 2012;48(10):385-6.

16. Molina R, Filella X, Augé J, et al. Tumor Markers (CEA, CA 125, CYFRA 21-1, SCC and NSE) in Patients with Non-Small Cell Lung Cancer as an Aid in Histological Diagnosis and Prognosis. Tumor Biol 2003;24:209-218.

17. Rottenberg Y, Nisman B, Peretz T. Extreme high levels of CA19-9 associated with adenocarcinoma of the lung. Isr Med Assoc J. 2009;11(2):116-117.

18. Molina R, Auge JM, Escudero JM, et al. Mucins CA 125, CA 19.9, CA 15.3 and TAG-72.3 as Tumor Markers in Patients with Lung Cancer: Comparison with CYFRA 21-1, CEA, SCC and NSE. Tumor Biol 2008;29:371-380.

19. Trapé J, Buxo J, Pérez de Olaguer J, Vidal C. Tumor markers as prognostic factors in treated non-small cell lung cancer. Anticancer Res. 2003;23(5b):4277-4281.

20. Giovanella L, Piantanida R, Ceriani L, et al. Immunoassay of NeuronSpecific Enolase (Nse) and Serum Fragments of Cytokeratin 19 (Cyfra 21.1) as Tumor Markers in Small Cell Lung Cancer: Clinical Evaluation and Biological Hypothesis. Int J Biol Markers 1997;12(1):22-26.

21. Cedrés $S$, Nuñez I, Longo $M$, et al. Serum tumor markers CEA, CYFRA21-1, and CA-125 are associated with worse prognosis in advanced non-smallcell lung cancer (NSCLC). Clin Lung Cancer. 2011;12(3):172-179.

22. Díez M, Torres A, Maestro M. et al. Prediction of survival and recurrence by serum and cytosolic levels of CEA, CA125, and SCC antigens in resectable non-small-cell lung cancer. Br J Cancer 73, 1248-1254 (1996). https://doi. org/10.1038/bjc.1996.239

23. Pecchio F, Rapellino M, Oliaro A et al. Luborarorio Baldi e Riberi, Ospedale S. Giovanni. Torino. Minerva Med 1988;79: 183-6.

24. Hatzakis KD, Froudarakis ME, Bouros D, Tzanakis N, Karkavitsas N, Siafakas NM. Prognostic value of serum tumor markers in patients with lung cancer. Respiration. 2002;69(1):25-29. 